\title{
Regulation of Microglial Development: A Novel Role for Thyroid Hormone
}

\author{
Flavia R. S. Lima, ${ }^{1}$ Annie Gervais, ${ }^{1}$ Catherine Colin, ${ }^{1}$ Mireille Izembart, ${ }^{2}$ Vivaldo Moura Neto, ${ }^{3}$ \\ and Michel Mallat ${ }^{1}$ \\ 1/nstitut National de la Santé et de la Recherche Médicale U.495, Hôpital de la Salpêtrière, 75651 Paris Cedex 13, \\ France, ${ }^{2}$ Service de Médecine Nucléaire, Hôpital Necker-Enfants Malades, 75743 Paris Cedex 15, France, and \\ ${ }^{3}$ Departamento de Anatomia, Instituto de Ciências Biomedicas, Universidade Federal do Rio de Janeiro, 21-949-900, \\ Rio de Janeiro, RJ, Brazil
}

The postnatal development of rat microglia is marked by an important increase in the number of microglial cells and the growth of their ramified processes. We studied the role of thyroid hormone in microglial development. The distribution and morphology of microglial cells stained with isolectin B4 or monoclonal antibody ED1 were analyzed in cortical and subcortical forebrain regions of developing rats rendered hypothyroid by prenatal and postnatal treatment with methyl-thiouracil. Microglial processes were markedly less abundant in hypothyroid pups than in age-matched normal animals, from postnatal day 4 up to the end of the third postnatal week of life. A delay in process extension and a decrease in the density of microglial cell bodies, as shown by cell counts in the developing cingulate cortex of normal and hypothyroid animals, were responsible for these differences. Conversely, neonatal rat hyperthyroidism, induced by daily injections of 3,5,3'-triiodothyronine (T3), ac- celerated the extension of microglial processes and increased the density of cortical microglial cell bodies above physiological levels during the first postnatal week of life.

Reverse transcription-PCR and immunological analyses indicated that cultured cortical ameboid microglial cells expressed the $\alpha 1$ and $\beta 1$ isoforms of nuclear thyroid hormone receptors. Consistent with the trophic and morphogenetic effects of thyroid hormone observed in situ, T3 favored the survival of cultured purified microglial cells and the growth of their processes. These results demonstrate that thyroid hormone promotes the growth and morphological differentiation of microglia during development.

Key words: microglia; cerebral cortex; thyroid hormone; thyroid hormone receptor; hypothyroidism; hyperthyroidism; triiodothyronine; rat; development
Microglia express markers specific to mononuclear phagocytes. Microglia are found throughout the CNS and are thought to be implicated in the pathophysiological responses to various lesions, including those caused by human infectious, inflammatory, or neurodegenerative diseases (Kreutzberg 1996; Antel and Owens, 1999; Gonzales-Scarano and Baltuch, 1999; Hickey, 1999). During development, microglial cells phagocytize cell debris in the CNS and produce factors that favor growth or degeneration of developing neurons (Ling and Wong, 1993; Chamak et al., 1995; Bertini et al., 1996; Elkabes et al., 1996; Frade and Barde, 1998). Microglial cells arise during the early stages of neurogenesis from infiltration of the neuroepithelium by mesodermal macrophage precursors. Microglial ontogenesis also involves intraparenchymal cell proliferation and differentiation of the motile ameboid

\footnotetext{
Received July 6, 2000; revised Nov. 27, 2000; accepted Dec. 22, 2000.

This work was supported by Institut National de la Santé et de la Recherche Médicale and grants from Ensemble Contre Le SIDA and from Electricité de France (EDF) to M.M. and by CAPES and Société des Amis des Sciences fellowships to F.R.S.L. We thank Drs. Patricia Oliveiro, Lydie Rappaport, and Jeanne Lyse Samuel for their contribution to this work, Drs. Jean-Luc Carré and Dominique Baas for their generous gift of polyclonal anti-rat TR antibodies, Dr. Louis Sarliève for valuable advice and stimulating discussions, and Drs. Bernard Zalc, José Luis Marín-Teva, and Merle Ruberg for critical reading of this manuscript.

Correspondence should be addressed to Dr. M. Mallat, Institut National de la Santé et de la Recherche Médicale U.495, Hôpital de la Salpêtrière, 47 boulevard de l'Hôpital, 75651, Paris Cedex 13, France. E-mail: michel.mallat@infobiogen.fr.

Dr. Lima's present address: Instituto de Biofisica Carlos Chagas Filho and Departamento de Anatomia, Instituto de Ciências Biomedicas, Universidade Federal do Rio de Janeiro, 21-949-900, Rio de Janeiro, RJ, Brazil.

Copyright (C) 2001 Society for Neuroscience 0270-6474/01/212028-11\$15.00/0
}

cells, commonly observed in the developing brain, into resting ramified cells (Cuadros and Navascués, 1998; Alliot et al., 1999; Marín-Teva et al., 1999).

The physiological factors that promote the growth and differentiation of microglial cells remain largely undetermined. Recent evidence indicates roles for neurotrophin-3 and colony stimulating factor-1 (CSF-1), which are expressed in the developing brain. (Michaelson et al., 1996; Calvo et al., 1998; Wegiel et al., 1998; Kahn et al., 1999).

In an attempt to characterize mechanisms regulating microglial growth, we have investigated the role of thyroid hormone [3,5,3'triiodothyronine (T3) and thyroxine (T4)]. These compounds favor basic processes of neurogenesis, including precursor cell proliferation, neuronal migration, dendritic and axonal growth, myelination, and synaptogenesis (Legrand, 1983; Porterfield and Hendrich, 1993; Bernal and Nunez, 1995). Thyroid hormone also acts as a promoter of astroglial and oligodendroglial differentiation and modulates proliferation of macroglial cells, depending on their stage of maturation and their localization in the brain (Rami and Rabié, 1988; Faivre-Sarrailh et al., 1991; Trentin et al., 1995; Lima et al., 1997, 1998; Rodríguez-Peña, 1999).

Thyroid hormone binds to receptors that belong to the nuclear receptor superfamily (Mangelsdorf et al., 1995). In humans and rodents, thyroid hormone receptors (TRs) are encoded by two genes, $\operatorname{TR} \alpha$ and $\operatorname{TR} \beta$, that generate multiple isoforms, among which only $\mathrm{TR} \alpha 1$, TR $\beta 1$, and $\mathrm{TR} \beta 2$ bind thyroid hormones (Muñoz and Bernal, 1997; Oppenheimer and Schwartz, 1997). 
$\operatorname{TR} \alpha$ and $\operatorname{TR} \beta$ are produced in the CNS, but their patterns of expression vary markedly according to developmental stages, cell phenotype, and intracerebral localization (Bradley et al., 1989, 1992; Strait et al., 1990, 1991; Mellström et al., 1991; Puymirat et al., 1991; Puymirat, 1992; Lechan et al., 1993; Carré et al., 1998). Notably they were not detected in all neurons or macroglial cells (Puymirat et al., 1991; Puymirat, 1992).

In the present study on hypothyroid- or hyperthyroiddeveloping rats, a major effect of thyroid hormone on the growth and morphological differentiation of microglia was observed. We also show that cultured microglial cells express $\operatorname{TR} \alpha 1$ and $\operatorname{TR} \beta 1$ and that T3, the active form of thyroid hormone, promotes their survival and the outgrowth of their processes. Together these results demonstrate that in addition to its previously well documented effects on neurons and macroglial cells, thyroid hormone plays a crucial role in the development of microglia.

\section{MATERIALS AND METHODS}

\section{In vivo experiments}

Animal treatment. All procedures were performed in accordance with the European Community Council Directive of November 24, 1986 (ref: $86 / 609 /$ CEE). Fetal and postnatal hypothyroidism was obtained by treatment of pregnant Wistar rats (IFFA CREDO, l'Arbresle, France) from day 16 of gestation [embryonic day 16 (E16)] with $0.1 \%$ 4-methyl-2thiouracil (MTU) (Fluka, St. Quentin Fallavier, France) in the drinking water and a low iodine food regimen ad libitum. MTU belongs to a family of compounds that block both maternal and fetal thyroid hormone synthesis by inhibiting thyroglobulin iodination (Lissitzky, 1990). The treatment was continued throughout lactation until the animals were killed. Classical signs of hypothyroidism, such as reduced weight and delayed eye opening in the pups, were observed.

Postnatal hyperthyroidism was induced by injecting developing rats daily with T3 [0.05 or $0.3 \mu \mathrm{g} / \mathrm{gm}$ body weight (wt), s.c.] (Sigma, St. Louis, $\mathrm{MO}$ ) from the day of birth until the day of perfusion. Groups of animals treated with MTU from E16 were also injected postnatally with T3 (0.05 or $0.3 \mu \mathrm{g} / \mathrm{gm}$ body $\mathrm{wt}$ ). Treated or saline-injected control pups remained with their dams until the day of perfusion.

Thyroxine assay. Hypothyroidism in the pups was controlled by radioimmunological assay (RIA) of total T4 in serum using the assay kit from Cis Bio International (Gif-sur-Yvette, France) according to the manufacturer's instructions.

Tissue processing. Deeply anesthetized MTU-treated and normal rats were perfused with fixative $2 \%$ paraformaldehyde (PFA), $55 \mathrm{~mm}$ L-lysine monohydrochloride, $10 \mathrm{~mm}$ sodium metaperiodate (Merck, Darmstadt, Germany), and $0.2 \%$ glutaraldehyde at postnatal day (P) 0, 4, 7, 10, 14, and 22. P0 corresponded to the day of birth. Rats injected with T3 or saline were perfused at $\mathrm{P} 4$ and P7. At least three animals were used for each treatment at each age. Brains were post-fixed in the same solution for $2 \mathrm{hr}$ at $4^{\circ} \mathrm{C}$, cryoprotected by overnight immersion in $20 \%$ sucrose in PBS $\left(4^{\circ} \mathrm{C}\right)$, and frozen rapidly. Coronal sections $(15 \mu \mathrm{m}$ thick) were cut on a cryostat, mounted onto gelatinized slides, air dried, and stored at $-20^{\circ} \mathrm{C}$ before use.

Immunohistochemical and lectin peroxydase staining. Microglial cells were stained on tissue sections with either Bandeiraea Simplicifolia isolectin B4 or mouse monoclonal antibody (mAb) ED1, as described previously (Chamak et al., 1995). For isolectin B4 labeling, sections were incubated overnight at $4^{\circ} \mathrm{C}$ with peroxidase-conjugated isolectin B4 (Sigma) diluted $(10 \mu \mathrm{g} / \mathrm{ml})$ in PBS supplemented with $0.1 \%$ Triton X-100 and $1 \mathrm{~mm}$ calcium. The specificity of the staining was checked by saturation of the lectin binding sites with $\mathrm{D}-(+)$-galactose $(300 \mu \mathrm{g} / \mathrm{ml})$. For immunoperoxidase staining, the sections were incubated with $\mathrm{mAb}$ ED1 (IgG1, Serotec, Bicester, UK) overnight at $4^{\circ} \mathrm{C}$ (dilution 1:100). The primary antibody was visualized using peroxidase-conjugated goat antimouse IgG (Biosys, Compiègne, France; dilution 1:200). The specificity was controlled by replacing the primary antibody with an unrelated mouse IgG1 (ICN, Eschwege, Germany). Peroxidase activity was re-

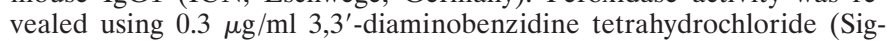
ma) in $100 \mathrm{~mm}$ Tris buffer, $\mathrm{pH}$ 7.4. The preparations were mounted in Eukit (Kindler, Freiburg, Germany) and observed under a Leitz DMRB microscope (Leica, Wetzlar, Germany).

Cell counts. The density of microglial cells revealed by isolectin B4- peroxydase staining was estimated in the suprastriatal region of the cingulate cortex. For each animal, counts were performed on four groups of 16 serial $15 \mu \mathrm{m}$ coronal sections, separated by gaps of $20-50 \mu \mathrm{m}$, depending on the developmental stages of animals, and covering 1-1.1 $\mathrm{mm}$ scale along the anteroposterior axis. Microglial cells bodies were scored at a magnification of $200 \times$ in two $0.25 \mathrm{~mm}^{2}$ grids per section. The fields were located in the cortical plate of the right and left cingulate cortex, external to the interhemispheric scissura just above the axonal fiber tract of the corpus callosum. Cell density was defined as the number of microglial cell bodies per field. The values presented are uncorrected cell counts (means \pm SEM) performed on sections from at least two animals for each age and each treatment. Statistical analyses were performed using the Kruskall-Wallis nonparametric ANOVA test followed by Dunn's multiple comparisons test.

\section{In vitro experiments}

Reagents for cell cultures. All cell types were cultured in plastic dishes (Nunc, Naperville, IL). T3, insulin, iron-free transferrin, progesterone, putrescin, and selenium were from Sigma. All other components of the culture media, including fetal calf serum (FCS) with low endotoxin content $(<0.05 \mathrm{ng} / \mathrm{ml})$, were obtained from Life Technologies (Cergy Pontoise, France). T3/T4-depleted FCS was obtained by adsorption of FCS $\left(2 \mathrm{hr}\right.$ at $\left.4^{\circ} \mathrm{C}\right)$ onto sterile analytical grade anion exchange resin (Bio-Rad, Hercules, CA) and verified by radioimmunological assay of total T4 and T3 levels (Cis Bio International).

Microglial cultures. Highly pure (>99\%) cultures of ameboid microglial cells were obtained as described previously (Théry et al., 1991). Briefly, floating microglial cells were isolated from 2-week-old primary glial cultures prepared from the cerebral cortex and striatum of E17 Wistar rats and grown in DMEM supplemented with $10 \%$ FCS. Harvested microglial cells were washed three times in FCS-free DMEM and plated in DMEM either with or without $1 \%$ T3/T4-depleted FCS. When used, T3 was added daily to the medium at a final concentration of $500 \mathrm{~nm}$.

For analysis of morphology and survival, microglial cells were plated at low cell densities in uncoated $6 \mathrm{~mm}$ plastic wells (5000 cells per well) to allow a clear observation of isolated cells. Biochemical analyses were performed on microglial cells plated in uncoated $60 \mathrm{~mm}$ dishes $(3.5 \times$ $10^{6}$ cells per dish).

Immunocytochemical and lectin fluorescent staining. Double-fluorescent staining of cultured microglial cells with isolectin B4 and various antibodies was performed as reported previously (Chamak et al., 1994), with slight modifications. Briefly, cells were fixed with $2 \%$ PFA before incubation overnight with fluorescein isothiocyanate (FITC)-conjugated isolectin B4 (Sigma; $5 \mu \mathrm{g} / \mathrm{ml}$ ), followed by cell permeabilization with $0.05 \%$ Triton X-100 and saturation (1 hr, room temperature) with $20 \%$ normal goat serum diluted in PBS. Cells were then incubated with rabbit polyclonal or mouse monoclonal anti-TR antibodies diluted 1:100 in PBS ( $1 \mathrm{hr}$, room temperature). Bound antibodies were revealed with tetramethylrhodamine isothiocyanate (TRITC)-conjugated goat anti-rabbit or anti-mouse IgG antibodies (Biosys, Compiègne, France). Four different antibodies reacting with TR of rat origins were used. Purified rabbit polyclonal anti-TR $\alpha$ antibodies raised against recombinant chicken TR $\alpha$ (ref:FL-408) and mouse monoclonal anti-TR $\beta 1$ IgG1 raised against an epitope mapping within the human TR $\beta 1$ (ref:J52) were obtained from Santa Cruz Biotechnology (TEBU, Le Perray-en-Yvelines, France). Rabbit polyclonal anti-TR $\alpha$ antibodies raised against a fragment of rat $\operatorname{TR} \alpha$ common to $\alpha 1$ and $\alpha 2$ isoforms (residues 17-33 within the $\mathrm{N}$-terminal region) and anti-TR $\beta 1$ antibodies raised against a fragment (residues 67-80) of rat TR $\beta 1$ were kindly provided by Dr. Baas (Ecole Normale Supérieure, Lyon, France) and Dr. Carré (Centre HospitaloRégional de Brest, France). Negative controls were obtained with unrelated rabbit or mouse $\operatorname{IgG}$ and by saturating FITC-conjugated lectin binding sites with D- $(+)$-galactose $(300 \mu \mathrm{g} / \mathrm{ml})$.

Survival, proliferation, and morphology of cultured microglial cells. For routine estimation of cell survival, cultured cells were fixed at different times after plating by incubation with $2.5 \%$ glutaraldehyde $(20 \mathrm{~min}$, at $4^{\circ} \mathrm{C}$ ) in culture medium. Cells were then washed extensively in PBS and incubated $10-15 \mathrm{~min}$ with $0.05 \%$ toluidine blue in $2 \% \mathrm{Na}_{2} \mathrm{CO}_{3}$. Stained cells were washed with distilled water, air dried, and examined with an inverted Nikon optical microscope (magnification $200 \times$ ). The number of surviving cells (before fixation) was estimated in each well. The criterion was morphological integrity of the nuclei, cytosplasm, and membranes. The reliability of this method was checked in pilot experiments by comparison with counts of cells displaying a dark precipitate after incubation of living cultures with 3-(4,5-dimethylthiazol-2yl)-2,5- 
Table 1. Sequences of RT-PCR primers, product sizes, and enzymes used for restriction analyses

\begin{tabular}{|c|c|c|c|c|}
\hline & Primer sequence & $\begin{array}{l}\text { Product } \\
\text { size } \\
\text { (bp) }\end{array}$ & $\begin{array}{l}\text { Enzyme (site } \\
\text { location, bp) }\end{array}$ & $\begin{array}{l}\text { Acces- } \\
\text { sion } \\
\text { number }\end{array}$ \\
\hline $\mathrm{TR} \alpha 1$ & $\begin{array}{l}\text { (For) 5'-TTGGAAACAGAGGCGAAAAT-3' } \\
\text { (Rev) 5'-GGGAGGAAGGAGAGAAGAGA-3' }\end{array}$ & 788 & PstI (408) & M18028 \\
\hline $\mathrm{TR} \alpha 2 \mathrm{vI} / \mathrm{TR} \alpha 2 \mathrm{vII}$ & $\begin{array}{l}\text { (For) 5'-TGACCCTGAGAGCGACACCC-3' } \\
\text { (Rev) 5'-CTCACTGCTGTCGTCTTCCC-3' }\end{array}$ & $598 / 481$ & $\begin{array}{l}\text { Bg11 (366/none) } \\
\text { EcoRI }(552 / 435)\end{array}$ & M31174 \\
\hline $\mathrm{TR} \beta 1$ & $\begin{array}{l}\text { (For) 5'-TTCCCTCTCCTTAGTCTGCT-3' } \\
\text { (Rev) 5'-GCCTCTTCTCACGGTTCTCT-3' }\end{array}$ & 710 & BamHI (322) & JO3819 \\
\hline $\mathrm{TR} \beta 2$ & $\begin{array}{l}\text { (For) 5'-ACCCCAAGACCTCCGTTTTT-3' } \\
\text { (Rev) 5'-TCGCCTCCGCACTCACACAA-3' }\end{array}$ & 785 & SfiI (430) & M25071 \\
\hline GAPDH & $\begin{array}{l}\text { (For) 5'-TATCGGACGCCTGGTTACCA-3' } \\
\text { (Rev) 5'-CATTGAGAGCAATGCCAGCC-3' }\end{array}$ & 875 & BglI (440) & X02231 \\
\hline
\end{tabular}

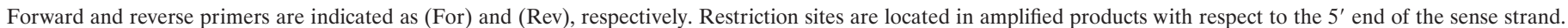

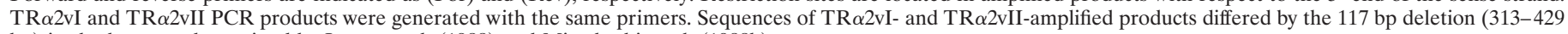
bp) in the latter as determined by Lazar et al. (1988) and Mitsuhashi et al. (1988b).

diphenyl tetrazolium bromide, a chromogenic compound that is commonly used in vitro to detect actively respiring cells (Denizot and Lang, 1986). Process-bearing cells were defined as those with at least one process three time longer than the diameter of the cell body. The number of surviving and process-bearing microglial cells was determined in eight microscopic grid fields covering $7 \%$ of the well surface.

Cells in S-phase were quantified by incorporation of bromodeoxyuridine (BrdU) into DNA using a cell proliferation kit from Amersham (Buckinghamshire, UK). Cultured cells were incubated for $24 \mathrm{hr}$ with BrdU before fixation and immunoperoxydase staining using anti-BrdU $\mathrm{mAb}$ according to the manufacturer's instructions. Stained nuclei were counted as above. The result was expressed relative to the average number of surviving cells in sister culture wells.

Statistical analyses were performed by ANOVA followed by StudentNewman-Keuls multiple comparison test or Student's $t$ test when just two groups were evaluated.

Reverse transcription-PCR analysis. Total RNA was isolated from cultured microglial cells, adult rat cerebral cortex, or pituitary lysed in guanidium isothiocyanate as described (Chomczynski and Sacchi, 1987). RNA $(3 \mu \mathrm{g})$ were reverse-transcribed for $50 \mathrm{~min}$ at $42^{\circ} \mathrm{C}$ using $200 \mathrm{ng}$ of random hexamer primers pdN6 (Pharmacia Biotech, Orsay, France) and $200 \mathrm{U}$ of Moloney Murine Leukemia Virus reverse transcriptase (Super Script II, Life Technology) in $50 \mu \mathrm{l}$ of reaction mixture containing (in $\mathrm{mm}$ ): 50 Tris-HCl, $\mathrm{pH} 8.3,75 \mathrm{KCl}, 3 \mathrm{MgCl}_{2}, 10 \mathrm{DTT}$, and $0.5 \mathrm{dNTP}$. Rat TR $\alpha 1$, TR $\alpha 2$, TR $\beta 1, \quad \operatorname{TR} \beta 2$, and glyceraldehyde-3-phosphatedehydrogenase (GAPDH) primers (Table 1) were chosen from reported cDNA sequences (Fort et al., 1985; Thompson et al., 1987; Koenig et al., 1988; Lazar et al., 1988; Hodin et al., 1989). TR $\alpha 2$ primers amplified two splice variants: TR $\alpha 2 \mathrm{vI}$ and TR $\alpha 2 \mathrm{vII}$ (Mitsuhashi et al., 1988a,b).

PCR was performed with $5 \mu \mathrm{l}$ of cDNA in $50 \mu \mathrm{l}$ of PCR reaction buffer containing 40 pmol of each primer, $0.4 \mathrm{~mm}$ dNTP, 2 U Taq DNA polymerase, $50 \mathrm{~mm} \mathrm{KCL}, 1.5 \mathrm{~mm} \mathrm{MgCl}_{2}, 10 \mathrm{~mm}$ Tris $\mathrm{HCl}$, $\mathrm{pH}$ 9, and $0.1 \%$ Triton $\mathrm{X}-100$. Thirty-two cycles of denaturation at $94^{\circ} \mathrm{C}$ for $30 \mathrm{sec}$, annealing at $55^{\circ} \mathrm{C}(\mathrm{TR} \alpha 1, \mathrm{TR} \beta 1, \mathrm{TR} \beta 2, \mathrm{GAPDH})$ or $59^{\circ} \mathrm{C}(\mathrm{TR} \alpha 2)$ for 40 sec, and extension at $72^{\circ} \mathrm{C}$ for $1 \mathrm{~min}$ were followed by a final elongation step at $72^{\circ} \mathrm{C}$ for $7 \mathrm{~min}$. Amplified products were analyzed by electrophoresis on $1.5 \%$ agarose gels.

No products were amplified from RNA samples that were not reversetranscribed or from purified genomic DNA, consistent with sequences spanning exon/intron borders (Lazar et al., 1989). The identity of amplified cDNA was verified by restriction enzyme analyses using the enzymes listed in Table 1.

\section{RESULTS}

\section{Microglial development in hypothyroid rats}

Rat pups treated with MTU from E16 showed signs of hypothyroidism (Porterfield and Hendrich, 1993), including reduced brain size and weight during early postnatal life. At birth (P0), brain weight of MTU-treated animals was normal: a mean of 232 mg (forebrain, midbrain, and hindbrain included) was obtained for four animals. This value rose to $316 \mathrm{mg}$ in MTU-treated P3 rats but remained $30 \%$ lower than in age-matched control animals (mean brain weight of $450 \mathrm{mg}$ ). The $25-35 \%$ reduction in brain weight in treated animals persisted in later developmental stages until P14. The effectiveness of the treatment was further confirmed by RIA assessement in serum of T4, the major circulating thyroid hormone. As expected from thyroid function in the developing rats (Fisher et al., 1977), T4 levels rose sharply in normal animals during the first 2 postnatal weeks of life. At birth, the $\mathrm{T} 4$ concentration in serum averaged $0.9 \mathrm{ng} / \mathrm{ml}$ and reached 18.8 and $52.4 \mathrm{ng} / \mathrm{ml}$ (means from two animals) at P7 and P14, respectively. In MTU-treated animals, T4 levels remained below the threshold of detection $(0.5 \mathrm{ng} / \mathrm{ml})$ up to at least P10 and was 13 times lower than in normal animals at P14 (3.9 ng/ml, mean of two hypothyroid animals).

Isolectin B4 binds specifically to microglial and endothelial cells on sections of developing and adult rat CNS (Streit and Kreutzberg, 1987; Ashwell, 1991; Sorokin et al., 1992; Chamak et al., 1995). Microglial cells were stained with this lectin in the forebrain of both normal and hypothyroid newborn rats (P0). Marked differences were observed, however, from P4. Microglial cells with branched processes were clearly detected in the cortical plate of normal P4 rats, but microglial cells appeared less abundant and overall had shorter and less ramified processes in the hypothyroid rats. These differences were most prominent at the level of the parietal region of the cerebral cortex (Fig. $1 \mathrm{~A}, B$ ). Quantification of microglial density was performed by cell counts in the ventral region of the cingulate cortex abuting the corpus callosum, to obtain consistent positioning of optic fields at different developmental stages. At P4 and P7 in the developing hypothyroid rat, microglial density was significantly lower than in matched normal rats ( $p<0.001$, Dunn's test) (Fig. 2A). In normal animals, the density of microglial cells remained stable from $\mathrm{P} 0$ to $\mathrm{P} 4$ and then increased to $\mathrm{P} 7$, whereas in hypothyroid pups, a $30 \%$ decrease occurred between birth and P4, followed by an increase to $\mathrm{P} 7$ (Fig. $2 A$ ).

Microglial development in hypothyroid rats remained subnormal at later developmental stages. From P7 to P14, microglia developed extensively in the normal cerebral cortex, as reported previously (Milligan et al., 1991; Chamak et al., 1995), and also in the cerebral cortex of hypothyroid rats, but not enough to compensate for the differences established during the first week of life 


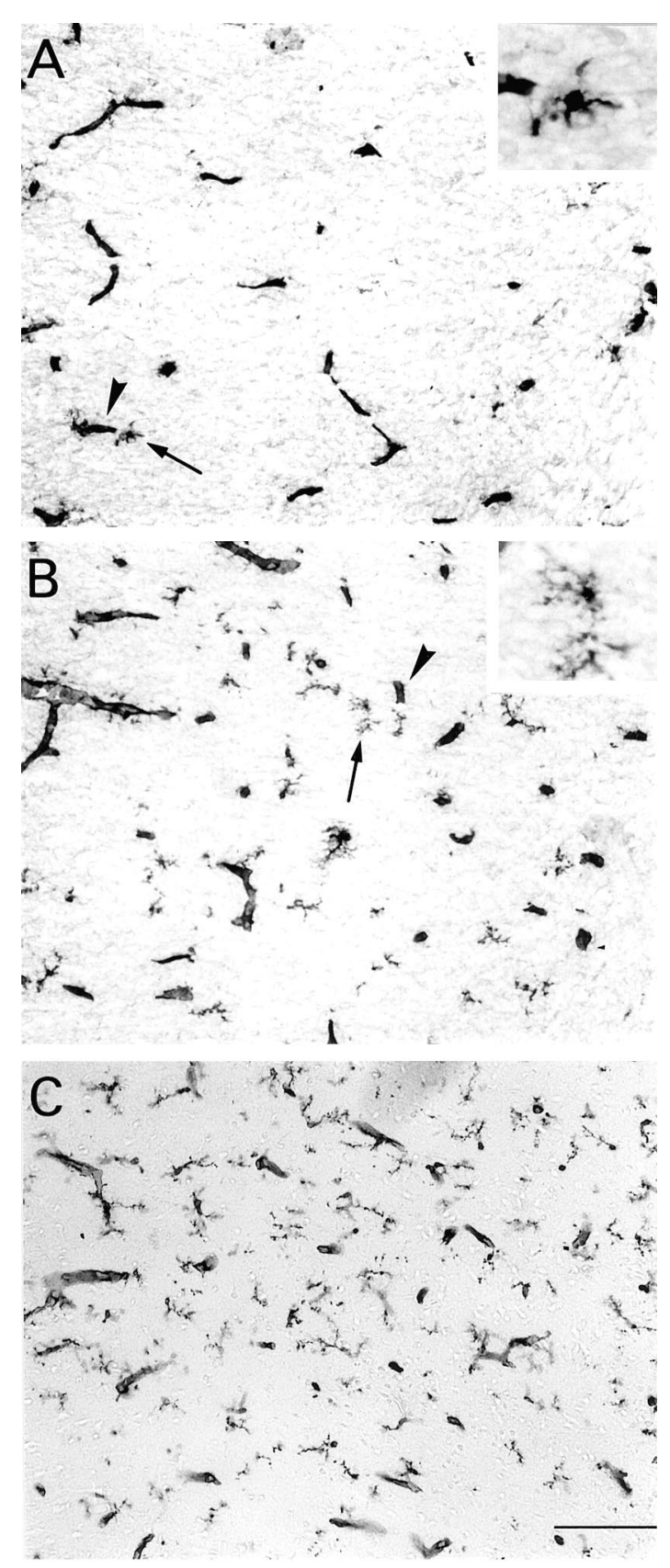

Figure 1. Microglial cells in the parietal cortex of hypothyroid $(A)$, euthyroid $(B)$, and hyperthyroid rats treated with $\mathrm{T} 3(0.3 \mu \mathrm{g} / \mathrm{gm}$ body wt) $(C)$ at $\mathrm{P} 4$. Representative fields in the cortical plate. Peroxidase staining with isolectin B4 reveals blood vessels (arrowheads) and branched microglial processes. $A, B$, Arrows point to microglial cells that are shown at higher magnification in the insets. Microglial cell bodies and processes appear more numerous from $A$ to $C$. Scale bar, $100 \mu \mathrm{m}$.

(Fig. 3A-D). At P22, isolectin staining of microglial cells was less intense than at P14, probably because of metabolic changes associated with the "resting" state of adult microglia (Perry et al., 1994). However, cortical microglia were still less developed at P22 in hypothyroid rats than in the normal animals (Fig. 3E,F). Microglial growth was similarly affected by hypothyroidism in other forebrain regions, including the corpus callosum, septal nuclei (Fig. 4), and striatum.

In addition to the marked modification of microglia, we noticed that enlarged isolectin B4-stained capillaries tended to be more
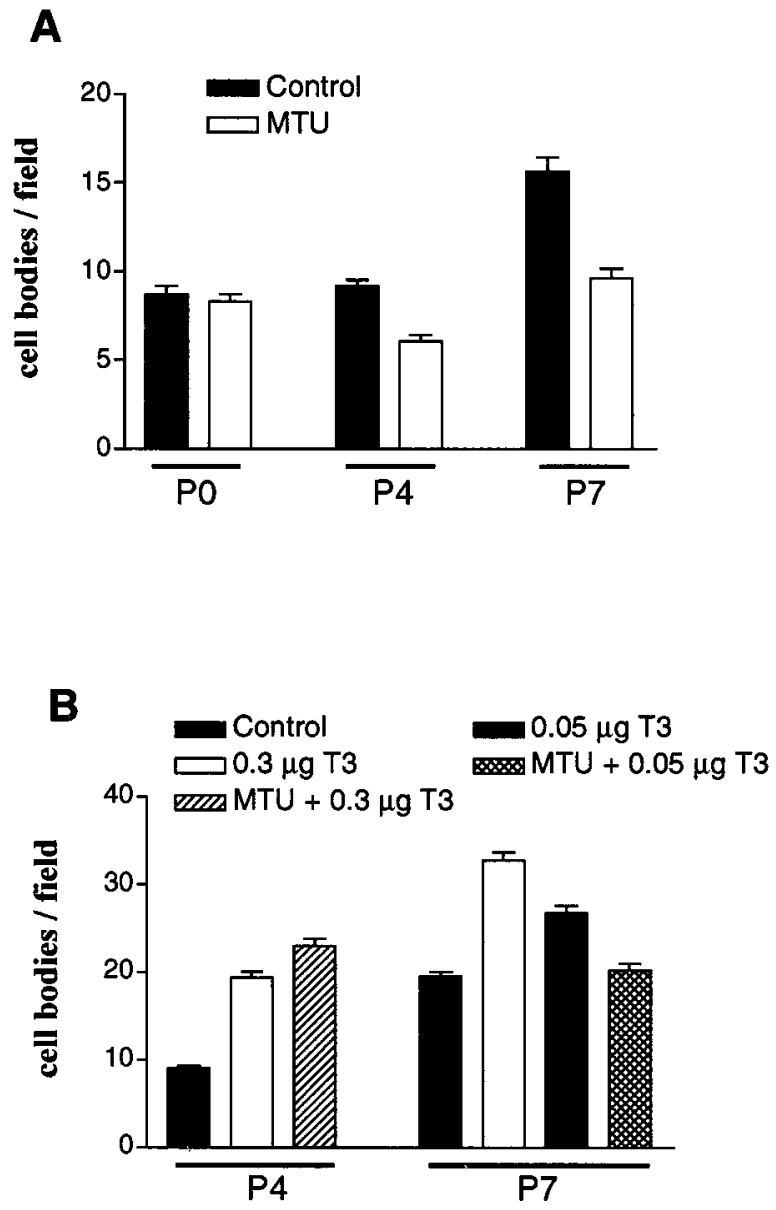

Figure 2. Microglial cell numbers in the cingulate cortex of hypothyroid, euthyroid, and hyperthyroid rats at $\mathrm{P} 0, \mathrm{P} 4$, and $\mathrm{P} 7$. Results are presented as the means \pm SEM of microglial cells stained with isolectin B4. $A$, Untreated euthyroid rats (Control) and MTU-treated hypothyroid rats $(M T U)$. Differences were significant between MTU-treated rats and controls at P4 and P7 $(p<0.001)$ and between MTU treatment at P4 and controls or MTU treatment at $\mathrm{PO}(p<0.01)$. B, Saline-injected euthyroid rats (Control), hyperthyroid rats injected with T3 at $0.3 \mu \mathrm{g}$ or $0.05 \mu \mathrm{g} / \mathrm{gm}$ body wt $(0.3 \mu \mathrm{g} T 3$ or $0.05 \mu \mathrm{g}$ T3), and MTU-treated rats that were injected with T3 at $0.3 \mu \mathrm{g}$ or $0.05 \mu \mathrm{g} / \mathrm{gm}$ body wt (MTU $+0.3 \mu \mathrm{g}$ T3 or $\mathrm{MTU}+0.05 \mu \mathrm{g} \mathrm{T} 3)$. At P4, differences between controls and T3-treated animals with or without MTU were significant $(p<0.001)$; differences between animals treated with T3 alone and animals treated with both MTU and T3 (T3 at $0.3 \mu \mathrm{g} / \mathrm{gm}$ body wt) were not significant ( $p>0.05$ ). At P7, there were significant differences between controls and T3-treated animals without MTU $(p<0.001)$ and between $0.3 \mu \mathrm{g}$ T3 and $0.05 \mu \mathrm{g}$ T3 treatments $(p<0.01)$. Differences between controls and animals treated with both MTU and T3 (T3 at $0.05 \mu \mathrm{g} / \mathrm{gm}$ body wt) were not significant $(p>0.05)$. Statistical analyses were performed using the Kruskall-Wallis nonparametric ANOVA test followed by Dunn's multiple comparisons test.

frequent in hypothyroid than in normal forebrain from the second postnatal week of life (Fig. 4D, arrowhead points to an enlarged vessel in hypothyroid corpus callosum at P10). Consistent with this observation, early morphometric analyses performed by Eayrs (1954) showed that the mean capillary diameter increased in the cerebral cortex of 24-d-old rats rendered hypothyroid from birth.

\section{Effects of T3 injection on microglial development}

The sensitivity of microglia to thyroid hormone was further studied by analyses of the microglial response to repeated injec- 


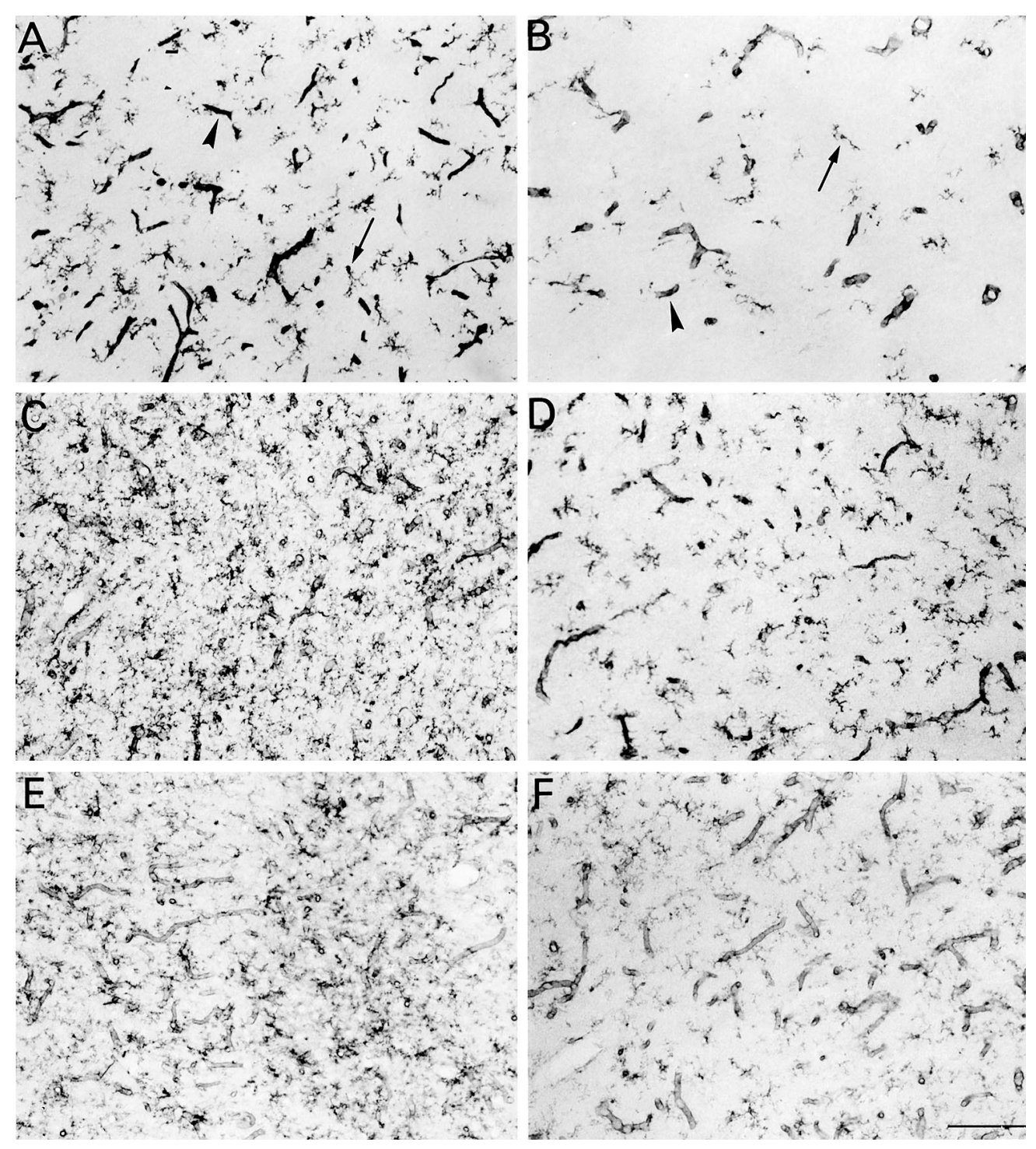

Figure 3. Developmental changes in microglia in the parietal cortex of euthyroid $(A, C, E)$ and hypothyroid $(B, D, F)$ rats at $\mathrm{P} 7(A, B), \mathrm{P} 14(C, D)$, and P22 $(E, F)$. Peroxidase staining with isolectin B4 in gray matter. Arrowheads and small arrows point to blood vessels and microglial cell bodies, respectively. Note the marked increase in microglial processes between P7 and P14, the reduced intensity of microglial staining at P22 compared with P7 or P14, and the reduced density of microglial processes in hypothyroid rats. Scale bar, $100 \mu \mathrm{m}$.

tions of T3. Isolectin B4 staining in brain sections of hyperthyroid $\mathrm{P} 4$ rats revealed an outgrowth of microglia in the forebrain, including the cerebral cortex (Fig. $1 B, C$ ). In the cingulate cortex, microglial cell density increased $100 \%$ in $\mathrm{P} 4$ rats treated with $0.3 \mu \mathrm{g}$ T3/gm body wt (Fig. 2B). At P7, hyperthyroidism was still associated with a significant increase in microglial density compared with controls ( $p<0.001$, Dunn's test) (Fig. 2B). Increases of 37 and $68 \%$ occurred in the cingulate cortex of P7 animals treated with 0.05 and $0.3 \mu \mathrm{g} \mathrm{T3/gm} \mathrm{body} \mathrm{wt,} \mathrm{respectively} \mathrm{(Fig.} 2 B$ ).

To determine whether lower hormone levels accounted for the reduced microglial density in MTU-treated hypothyroid rats, these animals were injected with $\mathrm{T} 3$ from the day of birth. T3 prevented the effects of prenatal and postnatal MTU treatment on microglial morphology and distribution in $\mathrm{P} 4$ and $\mathrm{P} 7$ rats. Microglial densities in the cingulate cortex were similar in P4 animals that received $0.3 \mu \mathrm{g} \mathrm{T} 3 / \mathrm{gm}$ body wt and in those treated with both T3 and MTU (Fig. 2B). Prolonged daily treatment of developing hypothyroid rats with doses of $\mathrm{T} 3>1 \mu \mathrm{g} / \mathrm{gm}$ body wt can compromise the survival of the animals (Cernohorsky et al., 1998). Thus, the effect of a 1 week T3 treatment in MTU-treated rats was analyzed using a dose of $0.05 \mu \mathrm{g} / \mathrm{gm}$ body wt. Under these conditions, the microglial density in rats treated with both MTU and T3 was restored at P7 to the level observed in control euthyroid rats (Fig. 2B).

$\mathrm{T} 3$ treatment also increased the development of cell processes. This was most obvious in the transient subpopulation of ameboid microglial cells labeled by mAb ED1 that are found mostly in developing axonal fiber tracts. During development, they can become ramified microglia and lose expression of macrophage markers, including the ED1 antigen (Milligan et al., 1991; Ling and Wong, 1993; Chamak et al., 1995).

As illustrated in Figure $5 A$, clusters of ED1-stained cells in the corpus callosum of $\mathrm{P} 7$ normal rats were roundish or elongated with short or no processes. In hyperthyroid rats, ED1-stained cells had long branched processes and smaller cell bodies (Fig. $5 B)$. Unlike isolectin B4-stained microglia, the density of ED1 
Figure 4. Microglial cells in the forebrain of euthryoid $(A, C, E)$ and hypothyroid rats $(B, D, F)$ at $\mathrm{P} 10 . A, B$, Cingulate cortex. $C, D$, Medial part of the corpus callosum; asterisks label the bottom of the interhemispheric scissura. $E, F$, Septal nuclei; peroxidase staining with isolectin B4. Arrowheads and small arrows point to blood vessels and microglial cell bodies, respectively. Overall, microglial cell processes are shorter in hypothyroid rats. Scale bar, $100 \mu \mathrm{m}$.

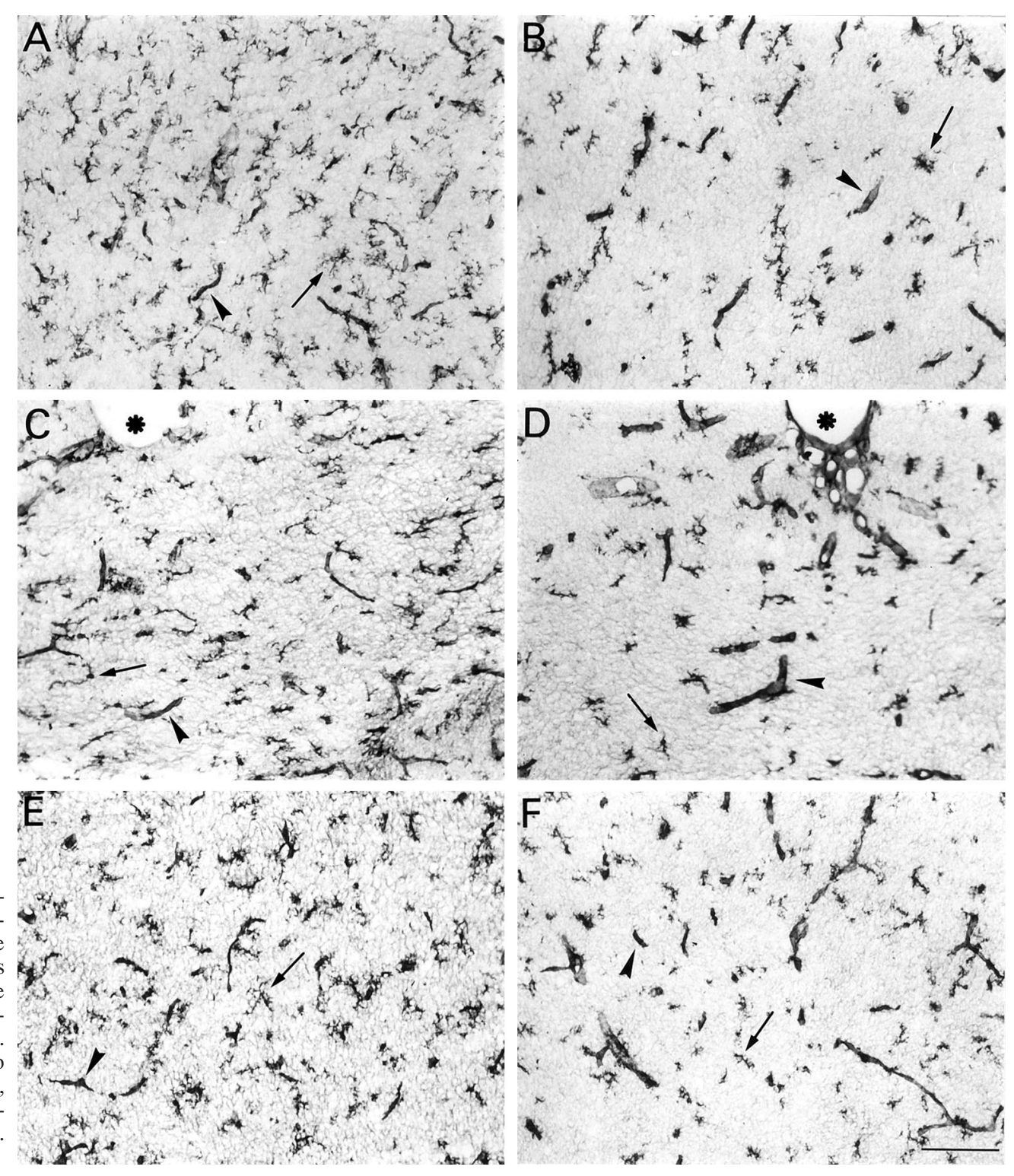

cells was not obviously increased after T3 treatment (Fig. 5), suggesting that hyperthyroidism did not prevent the developmental downregulation of ED1 antigen.

\section{Expression of TR by cultured microglial cells}

Histological analyses of developing hypothyroid and hyperthyroid rats indicated that thyroid hormone regulates growth and morphological differentiation of microglia. The possible direct influences of thyroid hormone on this cell population were investigated using cultures of purified microglial cells derived from developing cerebral cortex and striatum. These cells, freshly harvested from primary glial cultures, had an ameboid phenotype and expressed the ED1 antigen (Théry et al., 1991).

The expression of $\operatorname{TR} \alpha$ and $\operatorname{TR} \beta$ genes in microglial cultures was analyzed by reverse transcription (RT)-PCR. In addition to the three transcripts (TR $\alpha 1, \mathrm{TR} \beta 1, \mathrm{TR} \beta 2$ ) encoding isoforms that bind $\mathrm{T} 3$, we examined two closely related $\mathrm{TR} \alpha$ splice variants collectively designated $\mathrm{TR} \alpha 2$. These variants give rise to isoforms that do not bind T3, but they are expressed at high levels in the developing brain (Lazar et al., 1988; Mitsuhashi et al., 1988a; Strait et al., 1990). As illustrated in Figure 6A, TR $\alpha 1$ mRNA and
TR $\beta 1$ mRNA, but not TR $\beta 2$ or TR $\alpha 2$ transcripts, were detected in microglia kept in vitro for up to $24 \mathrm{hr}$ after purification from primary glial cultures. This pattern of expression was observed regardless of the presence of T3 or FCS in the culture medium (data not shown). Figure 6 shows that TR $\alpha 1$, TR $\alpha 2$, and TR $\beta 1$ or TR $\beta 2$ mRNA were clearly detected in adult cerebral cortex or in pituitary extracts used as positive controls (Hodin et al., 1989; Puymirat, 1992). Microglial expression of $\operatorname{TR} \alpha$ and $\operatorname{TR} \beta$ was demonstrated by immunocytochemical detection of the proteins (Fig. $6 C, E$ ) using antibodies raised against rat $\mathrm{TR} \alpha$ or rat $\mathrm{TR} \beta$, previously used to detect TR gene products in other CNS cell types (Baas et al., 1994; Carré et al., 1998). Counterstaining of the cells using isolectin B4 showed clearly that virtually all amoeboid microglial cells expressed both $\operatorname{TR} \alpha$ and $\operatorname{TR} \beta$ and that the receptors were preferentially located in the cell nuclei (Fig. $6 B-$ $E)$. Similar staining was also obtained with commercially available antibodies raised against chicken TR $\alpha$ or human TR $\beta 1$ proteins that cross-react with the rodent isoforms, and the microglial expression of $\operatorname{TR} \alpha$ and $\operatorname{TR} \beta$ proteins was confirmed by Western blots (data not shown). 

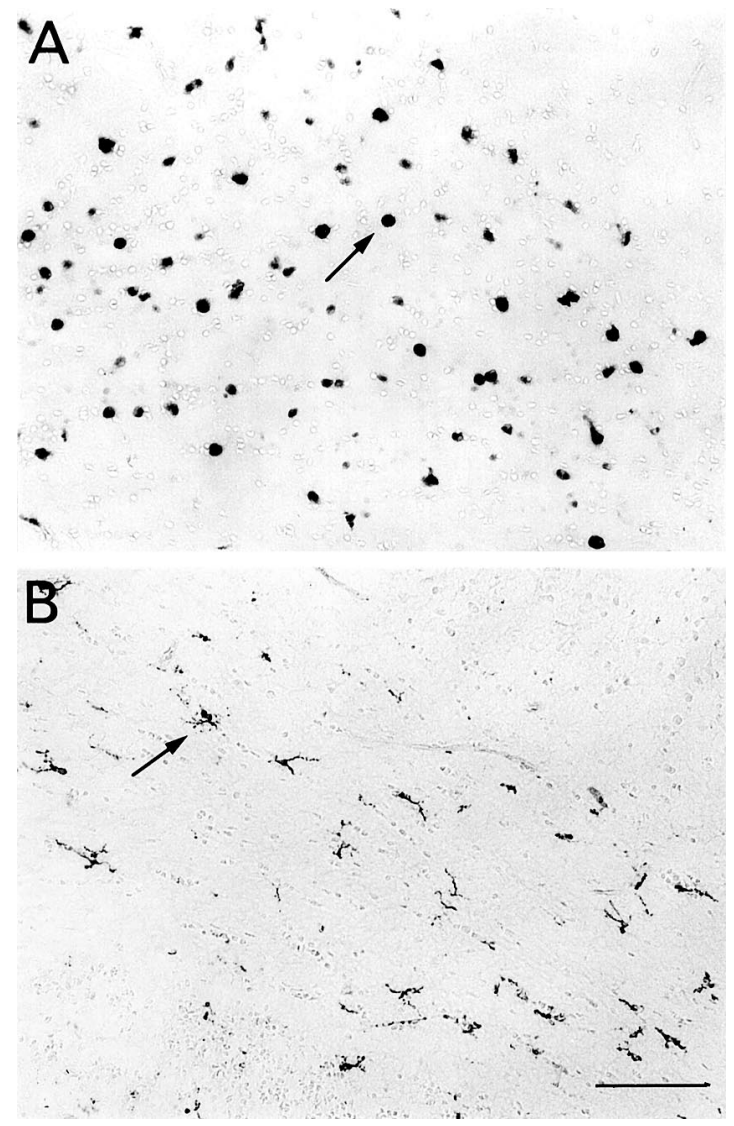

Figure 5. Macrophages in the corpus callosum of euthyroid $(A)$ and hyperthyroid rats treated with T3 $(0.3 \mu \mathrm{g} / \mathrm{gm}$ body wt) $(B)$ at P7. Fields localized above and lateral to the external edge of the lateral ventricle. Immunoperoxidase staining was with ED1 mAb. Arrows indicate two stained cells without $(A)$ or with $(B)$ processes. Note the presence of stained cells with long, branched processes in hyperthyroid animals $(B)$. Scale bar, $100 \mu \mathrm{m}$.

\section{T3 favors survival of purified microglia}

Isolated microglial cells were seeded at low cell densities in DMEM supplemented with 1\% T3/T4-depleted FCS, the only source of growth factors. In these conditions, the number of surviving cells remained stable for at least $24 \mathrm{hr}$ (data not shown) but dropped to $<50 \%$ of the initial number after $2 \mathrm{~d}$, and another $25 \%$ after $3 \mathrm{~d}$, in culture (Fig. 7). Addition of T3 (500 nM) to the culture medium significantly increased the number of surviving cells both 2 and $3 \mathrm{~d}$ after isolation ( $p<0.01$; Student-NewmanKeuls test) but did not completely prevent microglial degeneration (Fig. 7).

A possible mitogenic effect of T3 was investigated by immunocytochemical labeling and counts of cells that incorporated BrdU. In cultures treated for $24 \mathrm{hr}$ with $\mathrm{T} 3,<10 \%$ of the surviving cells incorporated BrdU. T3 therefore prevented the death of microglial cells rather than promoting their proliferation.

\section{T3 stimulates growth of microglial processes}

Cultures were also used to investigate the direct influence of T3 on the morphology of microglial cells. The experiments were performed using FCS-free culture medium because FCS interferes with the morphological differentiation of cultured microglial cells (Chamak and Mallat, 1991). Ameboid microglial cells freshly isolated from primary glial cultures had flat, rounded cell bodies. In serum-free medium, they progressively elongated and
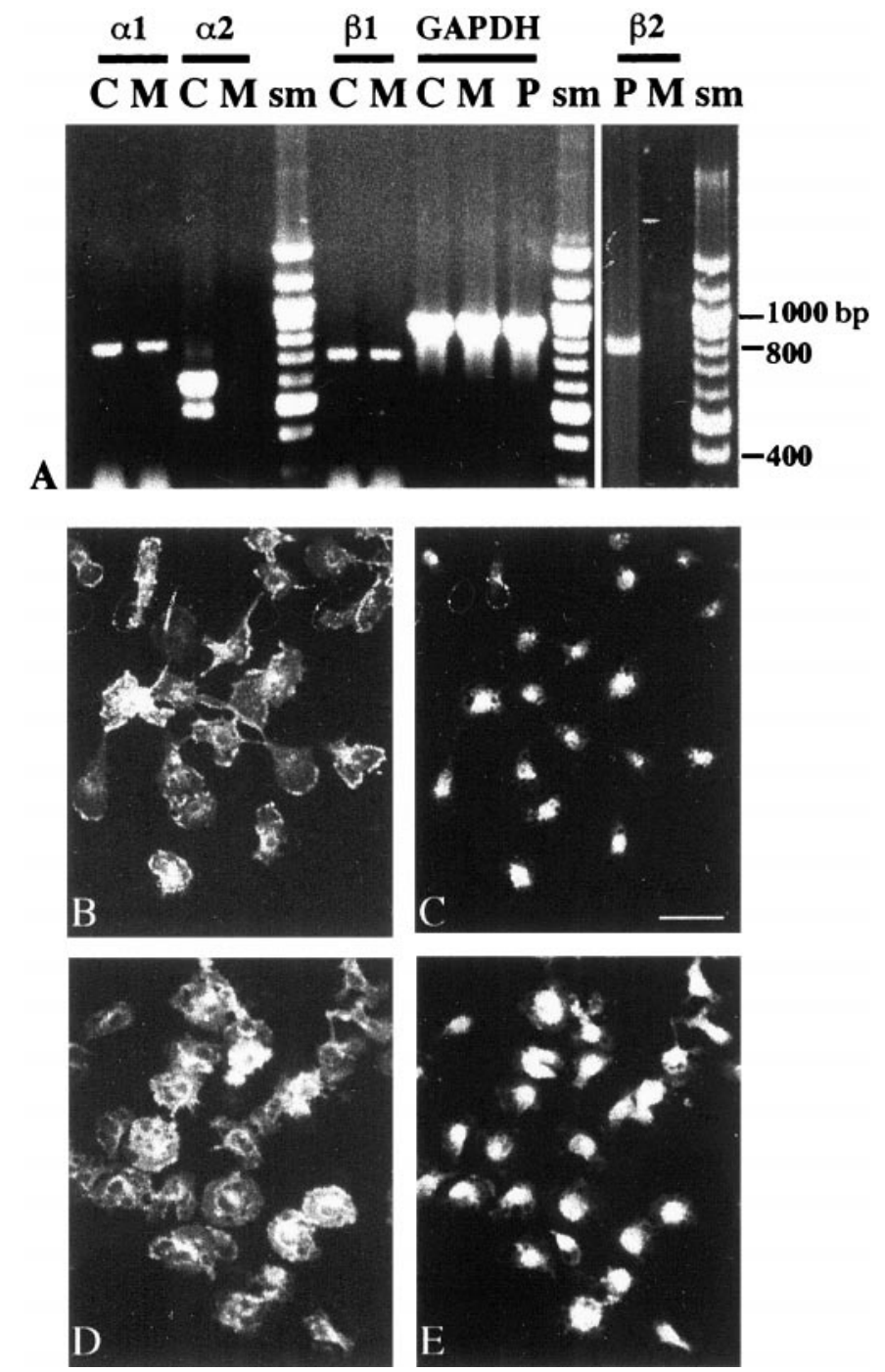

Figure 6. Expression of TR genes in cultured microglial cells. A, RTPCR analysis. Ethidium bromide-stained agarose gel of RT-PCR products generated from TR $\alpha 1$, TR $\alpha 2$, TR $\beta 1$, TR $\beta 2$, and GAPDH mRNAs $(\alpha 1$, $\alpha 2, \beta 1, \beta 2$, and GAPDH). Total RNA was extracted from cultures of ameboid microglial cells $(M)$ kept $1 \mathrm{~d}$ in vitro after purification from primary glial cultures. RNA from adult rat cerebral cortex $(C)$ was used as positive control for $\operatorname{TR} \alpha 1, \mathrm{TR} \alpha 2$, and $\mathrm{TR} \beta 1$ amplifications. TR $\alpha 2$ amplified products generated with the same primers appear as two bands in the same lane $(\alpha 2 / C)$ and correspond to $\mathrm{TR} \alpha 2 \mathrm{vI}$ (top band) and TR $\alpha 2$ vII. A TR $\beta 2$-amplified product was obtained from adult pituitary $(P)$ RNA. TR $\alpha 1$ and TR $\beta 1$ were the only TR isoforms detected in microglial mRNA. Comparable levels of GAPDH-amplified products were obtained from the different RNA preparations. sm, Molecular size marker. Immunocytochemical detection of $\operatorname{TR} \alpha$ and $\operatorname{TR} \beta$ in microglial cultures $(B, C, D, E)$ is shown. Purified microglial cells were kept for $1 \mathrm{~d}$ in vitro before fixation. Double staining of fixed cells with isolectin B4 (FITC, $B$ ) and rabbit polyclonal antibodies raised against rat $\operatorname{TR} \alpha$ (TRITC, $C$ ) is shown. Staining with isolectin B4 (FITC, $D$ ) and rabbit polyclonal antibodies raised against rat $\operatorname{TR} \beta$ (TRITC, $E$ ) is shown. Scale bar, $30 \mu \mathrm{m}$.

emitted processes. As illustrated in Figure 8, $A$ and $B$, the addition of T3 to the medium strongly stimulated process extension. Process-bearing microglia, defined as cells with at least one thin process three times longer than the cell body (usually $>100 \mu \mathrm{m}$ ), were counted. T3 exposure for $48 \mathrm{hr}$ doubled the proportion of process-bearing cells (Fig. $8 C$ ). 


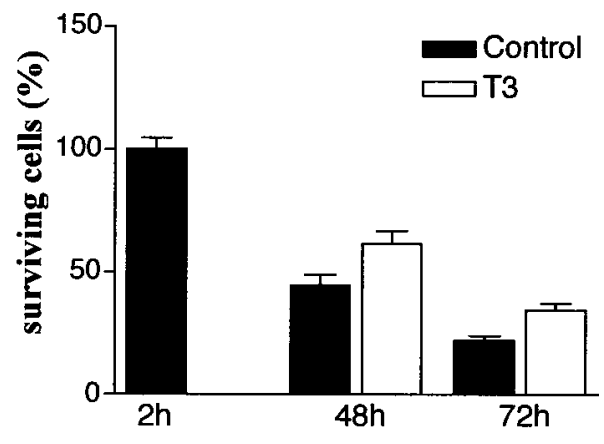

Figure 7. Influence of $\mathrm{T} 3$ on the survival of cultured microglial cells. Purified microglial were plated (5000 cells per well) in DMEM containing $1 \% \mathrm{~T} 3 / \mathrm{T} 4-$ depleted FCS. The cells were cultured in this medium without (Control) or with T3 (500 nM), which was added $3 \mathrm{hr}$ after plating. The number of surviving cells was determined at the indicated time and is expressed as percentage of the mean control value determined $2 \mathrm{hr}$ after plating. Data are means \pm SEM of four independent experiments with three to four determinations in sister wells per experiment. The actual number of surviving cells counted in each well $2 \mathrm{hr}$ after plating (control value) (see Materials and Methods) always exceeded 100. Differences between control and T3-treated cultures were significant at 48 and $72 \mathrm{hr}$ $(p<0.01)$ according to comparisons by one-way ANOVA followed by Student-Newman-Keuls multiple comparisons test.

\section{DISCUSSION}

This study shows for the first time that thyroid hormone plays a major role in microglial ontogenesis. The density of microglial cells was reduced, as was microglial process formation in the forebrain of developing rats deprived of thyroid hormone from a late fetal stage of life. Conversely, neonatal rat hyperthyroidism increased the density of microglial cells and the growth of microglial processes during the first postnatal week. TR $\alpha 1$ and TR $\beta 1$ were detected in the nuclei of cultured microglial cells, and T3 was found to favor the in vitro survival of purified microglial cells and the growth of their processes.

\section{Thyroid hormone favors microglia expansion: early postnatal life as a critical period}

We observed reduced microglial development up to P22 in hypothyroid brain. The early postnatal stages, however, appeared to be critical for thyroid hormone-stimulated accumulation of microglial cells. The density of microglial cells in the cingulate cortex of hypothyroid rats dropped below normal levels between P0 and $\mathrm{P} 4$, whereas injection of T3 during this period of development increased microglial density above normal levels, suggesting that during this developmental period the low endogenous production of thyroid hormone (Fisher et al., 1977) could limit the growth of cortical microglia. In contrast, between P4 and P7, cortical microglia expanded in both normal and hyperthyroid rats, but also in hypothyroid animals. Thus, the first postnatal week of life is a critical period for thyroid hormone action on developing cortical microglia.

Thyroid hormone in fetal rats is supplied by the mother and, from E17, by the fetal thyroid (Fisher et al., 1977; Kawaio and Tsuneda, 1985). In our study, hypothyroid rats were obtained by continuous administration, from E16, of an anti-thyroid drug (MTU) that inhibited both maternal and fetal thyroid glands. Although recent studies show that thyroid hormone regulates gene expression in fetal rat brain (Alvarez-Dolado et al., 1999; Dowling et al., 2000), we saw no clear influence of thyroid hormone on microglial development during late fetal stages. The distribution of the cells in newborn hypothyroid rats and, more specifically, their density in the cingulate cortex were normal. Moreover, fetal thyroid hormone deprivation did not significantly alter the early microglial response to $\mathrm{T} 3$ administered at birth (Fig. 2B, P4). However, microglial cells were already present in the developing rat brain at E12 (Ashwell, 1991; Sorokin et al., 1992), $4 \mathrm{~d}$ before the beginning of MTU treatment (E16). Early transplacental transfer of thyroid hormones from the mother (Obregon et al., 1984; Porterfield and Hendrich, 1992) therefore might have influenced the early fetal development of the microglial cells.

\section{Thyroid hormone promotes morphological differentiation of microglia}

The maturation of microglial cells is characterized by the progressive growth of ramified processes that distinguish these cell populations from other tissue phagocytes (Perry et al., 1994). In cultured microglial cells, extracellular matrix proteins, CSFs, retinoic acid, and vitamin $\mathrm{E}$ have been shown to promote the in vitro growth of microglial processes (Giulian and Baker, 1986; Chamak and Mallat, 1991; Liu et al., 1994; Fujita et al., 1996; Heppner et al., 1998). The effect of CSF-1 appears to be physiologically relevant because microglial cells have shorter processes in the frontal cortex of adult mice that are genetically deficient for CSF-1 (Wegiel et al., 1998).

Our results indicate that thyroid hormone stimulates the developmental growth of microglial processes, which are reduced in hypothyroid and increased in hyperthyroid pups. These animals differed from normal pups from P4. The morphogenetic effect of thyroid hormone was supported by the presence of clusters of process-bearing cells expressing ED1 antigen in $\mathrm{P} 7$ hyperthyroid rats.

The ED1 antigen is a glycosylated protein in membranes of phagolysosomes and in the cytosol of macrophages. Its expression appears to correlate with phagocytic activity (Bauer et al., 1994; Damoiseaux et al., 1994). In the postnatal developing rat brain, the ED1 antigen is a hallmark of a transient population of ameboid microglia. These cells have enlarged cell bodies with no or short processes and are engaged in phagocytosis (Milligan et al., 1991; Ling and Wong, 1993; Chamak et al., 1995). Our observations suggest that an excess of T3 levels can disrupt the synchronization of two major events characterizing the normal transformation of ameboid microglia into ramified microglia: the loss of phagocytic behavior and the extension of long and branched processes.

\section{Pathways for thyroid hormone influences on microglia: assessment of the direct microglial responses to T3}

The effects of thyroid hormone on microglial development are likely to involve a complex integration of T3-dependent endocrine and paracrine mechanisms. In particular, thyroid hormone could possibly act by modulating the neuronal or macroglial production of factors such as neurotrophin-3, which is known to favor microglial proliferation (Elkabes et al., 1996; Neveu and Arenas, 1996). Likewise, microglial responses to hypothyroidism or hyperthyroidism could be strongly determined by functional changes or alterations in the development of neuronal or macroglial cell populations. However, our in vitro study revealed that T3 also acts directly on microglial cells and suggests that these effects could account in part for the in situ response of microglial cells.

T3 favored the survival of purified ameboid microglial cells in vitro. The trophic effects of T3 were observed under culture conditions in which serum concentration and cell densities were 

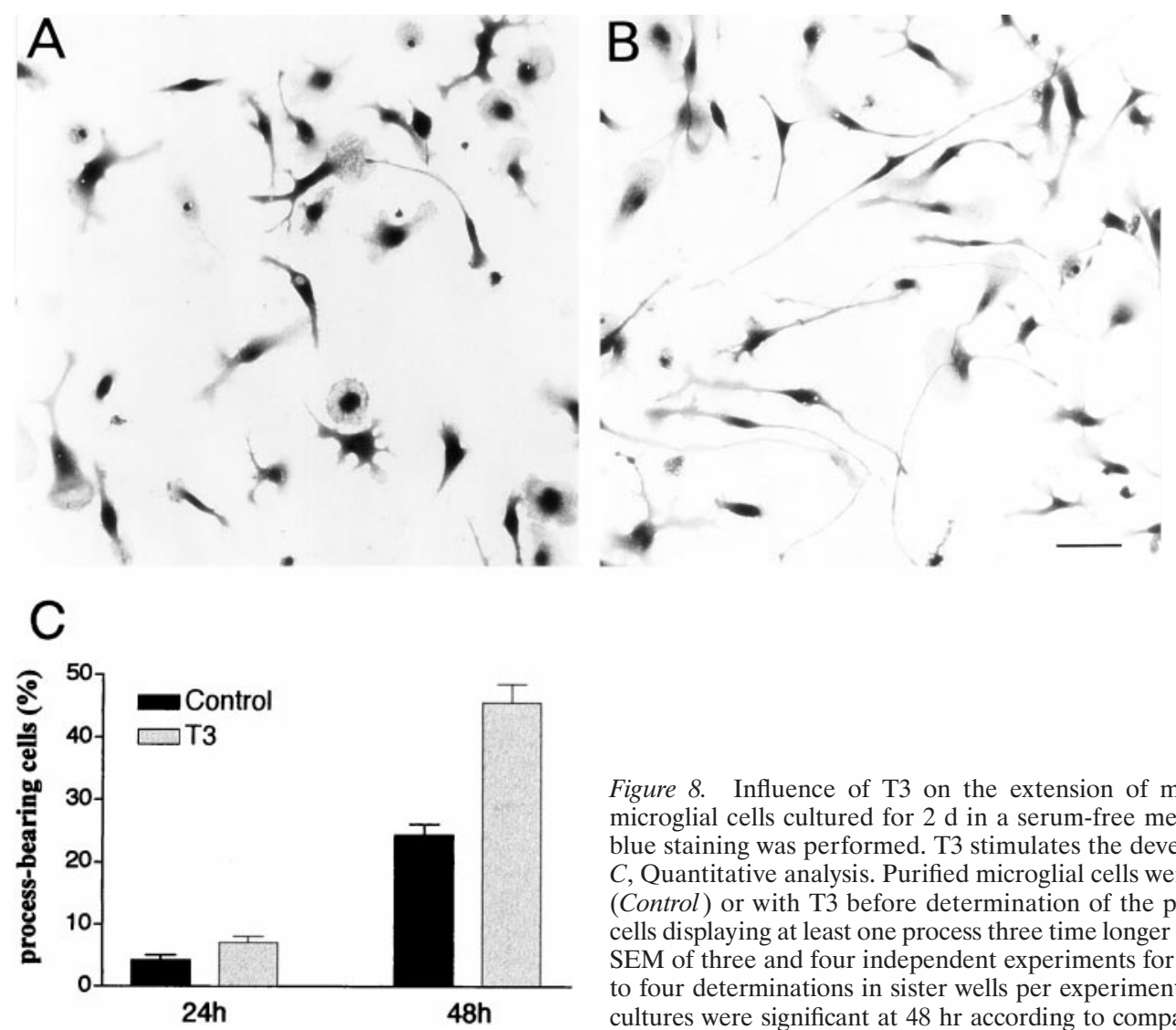

Figure 8. Influence of T3 on the extension of microglial processes. Morphology of purified microglial cells cultured for $2 \mathrm{~d}$ in a serum-free medium without $(A)$ or with $(B)$ T3. Toluidine blue staining was performed. T3 stimulates the development of long processes. Scale bar, $50 \mu \mathrm{m}$. $C$, Quantitative analysis. Purified microglial cells were cultured for 24 or $48 \mathrm{hr}$ in DMEM without (Control) or with T3 before determination of the proportion of process-bearing cells defined as cells displaying at least one process three time longer than the cell body diameter. Data are means \pm SEM of three and four independent experiments for 24 and $48 \mathrm{hr}$ cultures, respectively, with three to four determinations in sister wells per experiment. Differences between control and T3-treated cultures were significant at $48 \mathrm{hr}$ according to comparisons with Student's $t$ test $(p<0.001)$.

low, thereby limiting contributions of undefined exogenous compound or endogenous factors released by microglial cells. This contrasts with the death-promoting effect of T3 on other mesodermal derivatives, including erythrocytic progenitors and osteoblastic and promyeloleukemic cells (Gandrillon et al., 1994; Suzuki et al., 1997; Varga et al., 1999), or the lack of direct influence of T3 on the survival of oligodendrocytes and their precursors (Rodríguez-Peña, 1999). However, T3 also directly supports survival of neuronal subpopulations (Filipcik et al., 1994; Muller et al., 1995).

During development, the expansion of microglia, like that of neuroectodermal derivatives, is limited by cell death (Ling and Wong, 1993). Although the role of cell death in the difference between microglial density in normal and hypothyroid or hyperthyroid rats remains to be clarified, the effect of T3 on purified cortical microglial cells appears consistent with the loss of microglial cells in vivo, which would explain the decreased density of these cells in the cingulate cortex of hypothyroid rats at P4.

Similar to other neural cells (Walter, 1996; Baas et al., 1997; Lima et al., 1997), purified ameboid microglial cells respond to T3 exposure by increased extension of cell processes, an important step in their acquisition of a ramified phenotype. As for the effect on cell survival, it may be hypothesized that increased or decreased levels of $\mathrm{T} 3$ reaching microglial cells contribute to augment or reduce microglial process formation in hyperthyroid and hypothyroid rats, respectively.

There is a general agreement that the cellular effects of T3 are mediated via the nuclear receptors $\operatorname{TR} \alpha 1, \mathrm{TR} \beta 1$, or $\mathrm{TR} \beta 2$, which modulate transcription of targets genes through binding to specific DNA acceptor sites known as T3 responsive elements (Muñoz and Bernal, 1997). In the present study, ame- boid microglial cells freshly purified from 2 -week-old primary glial cultures expressed both TR $\alpha 1$ and TR $\beta 1$ mRNA and the related proteins but not the TR $\beta 2$ isoform, which was detected, however, in the developing and adult CNS (Bradley et al., 1992; Lechan et al., 1993). This does not rule out another pattern of TR gene expression in cells of the microglial lineage that include precursors derived from hemopoietic organs or ramified microglial cells. Indeed, the TR isoforms expressed in other CNS cell lineages are reported to change as a function of the stage of cell differentiation (Puymirat, 1992; Carré et al., 1998). The respective roles of $\operatorname{TR} \alpha 1$ and $\operatorname{TR} \beta 1$, their target genes, and the downstream molecular events that account for T3-increased microglial survival or process growth remain to be clarified. The study of mice deficient for $\operatorname{TR} \alpha, \operatorname{TR} \beta$, or both types of receptors (Göthe et al., 1999) should help answer this question. Interestingly, Arpin et al. (2000) showed that 17-dold $\operatorname{TR} \alpha$-deficient mice had reduced numbers of splenic macrophages compared with wild-type littermates. Whether this results from altered expression of $\mathrm{TR}$ in macrophages or in other splenic or non-splenic cells has not been determined. Because of the intrinsic biological activity of unbound TR (Muñoz and Bernal, 1997), it will be important to assess the effect of thyroid hormone on the development of peripheral macrophages in animals with genetically normal TR gene expression, as in our study.

\section{Conclusions}

Our study demonstrates that thyroid hormone supports the expansion and morphological maturation of microglia. In addition to the identification of a physiological factor regulating microglial development, this finding may help to understand the effects of 
thyroid hormone on cells of neuroectodermal origin during development. In particular, control of the number of microglial cells by thyroid hormone could regulate the availability of microglialderived growth factors that act on neurons or astrocytes (Giulian et al., 1988; Chamak et al., 1994, 1995; Elkabes et al., 1996). Our results also suggest that thyroid hormone might influence microglial reactions that accompany lesions or neurodegenerative diseases in the CNS and could regulate microglial functions. These questions deserve further investigation.

\section{REFERENCES}

Alliot F, Godin I, Pessac B (1999) Microglia derive from progenitors originating from the yolk sac and which proliferate in the brain. Dev Brain Res 117:145-152.

Alvarez-Dolado M, Ruiz M, Del Rio J, Alcantara S, Burgaya F, Sheldon M, Nakajima K, Bernal J, Howell BW, Curran T, Soriano E, Muñoz A (1999) Thyroid hormone regulates reelin and dab1 expression during brain development. J Neurosci 19:6979-6993.

Antel JP, Owens T (1999) Immune regulation and CNS autoimmune disease. J Neuroimmunol 100:181-189.

Arpin C, Pihlgren M, Fraichard A, Aubert D, Samarut J, Chassande O, Marvel J (2000) Effects of T3R alpha 1 and T3R alpha 2 gene deletion on $\mathrm{T}$ and $\mathrm{B}$ lymphocyte development. J Immunol 164:152-160.

Ashwell K (1991) The distribution of microglia and cell death in the fetal rat forebrain. Dev Brain Res 58:1-12.

Baas D, Fressinaud C, Ittel ME, Reeber A, Dalençon D, Puymirat J, Sarliève LL (1994) Expression of thyroid hormone receptor isoforms in rat oligodendrocyte culture. Effect of 3,5,3'-triiodo-L-thyronine. Neurosci Lett 76:47-51.

Baas D, Bourbeau D, Sarlieve L, Ittel M-E, Dussault JH, Puymirat J (1997) Oligodendrocyte maturation and progenitor cell proliferation are independently regulated by thyroid hormone. Glia 19:324-332.

Bauer J, Sminia T, Wouterlood FG, Dijkstra CD (1994) Phagocyting activity of macrophages and microglial cells during the course of acute and chronic relapsing experimental autoimmune encephalomyelitis. J Neurosci Res 38:365-375.

Bernal J, Nunez J (1995) Thyroid hormones and brain development. Eur J Endocrinol 133:390-398.

Bertini G, Savio T, Zaccheo D, Schmidt HHHW, Bentivoglio M (1996) NADPH-diaphorase activity in brain macrophage during postnatal development in the rat. Neuroscience 70:287-293.

Bradley DJ, Young WS, Weinberger C (1989) Differential expression of $\alpha$ and $\beta$ thyroid hormone receptors genes in rat brain and pituitary. Proc Natl Acad Sci USA 86:7250-7254.

Bradley DJ, Towle HC, Young WS (1992) Spatial and temporal expression of $\alpha$ - and $\beta$-thyroid hormone receptor mRNAs, including the $\beta 2$ subtype, in developing mammalian nervous system. J Neurosci 12:2288-2302.

Calvo CF, Dobbertin A, Gelman M, Glowinski J, Mallat M (1998) Identification of CSF-1 as a brain macrophage migratory activity produced by astrocytes. Glia 24:180-186.

Carré J-L, Demerens C, Rodrigues-Pena A, Floch HR, Vicendon G, Sarliève L (1998) Thyroid hormone receptor isoforms are sequentially expressed in oligodendrocyte lineage cells during rat cerebral development. J Neurosci Res 54:584-594.

Cernohorsky J, Frantisek K, Pelouch V, Korecky B, Vetter R (1998) Thyroid control of sarcolemmal $\mathrm{NA}^{+} / \mathrm{Ca} 2^{+}$-ATPase in developing rat heart. Am J Physiol 275:H264-H273.

Chamak B, Mallat M (1991) Fibronectin and laminin regulate the in vitro differentiation of microglial cells. Neuroscience 45:513-527.

Chamak B, Morandi V, Mallat M (1994) Brain macrophages stimulate neurite growth and regeneration by secreting thrombospondin. J Neurosci Res 38:221-233.

Chamak B, Dobbertin A, Mallat M (1995) Immunohistochemical detection of thrombospondin in microglia in the developing rat brain. Neuroscience 69:177-187.

Chomczynski P, Sacchi N (1987) Single step method of RNA isolation by acid guanidium thiocyanate phenol chloroform extraction. Anal Biochem 162:156-159.

Cuadros MA, Navascués J (1998) The origin and differentiation of microglial cells during development. Prog Neurobiol 56:173-189.

Damoiseaux JGMC, Döpp EA, Calame W, Chao D, McPherson GG, Dijkstra CD (1994) Rat macrophage lysosomal membrane antigen recognized by monoclonal antibody ED1. Immunology 83:140-147.

Denizot F, Lang R (1986) Rapid colorimetric assay for cell growth and survival. Modification to the tetrazolium procedure giving improved sensitivity and reliability. J Immunol Methods 89:271-277.

Dowling ALS, Martz GU, Leonard JL, Zoeller RT (2000) Acute changes in maternal thyroid hormone induce rapid and transient changes in gene expression in fetal rat brain. J Neurosci 20:2255-2265.
Eayrs JT (1954) The vascularity of the cerebral cortex in normal and cretinous rats. J Anat 88:164-173.

Elkabes ST, Di Cicco-Bloom EM, Black IB (1996) Brain microglia/ macrophages express neurotrophins that selectively regulate microglial proliferation and function. J Neurosci 16:2508-2521.

Faivre-Sarrailh C, Rami A, Fages C, Tardy M (1991) Effect of thyroid deficiency on glial fibrillary acidic protein (GFAP) and GFAP-mRNA in the cerebellum and hippocampal formation of the developing rat. Glia 4:272-284.

Filipcik P, Saito H, Katsuki H (1994) 3,5,3'-L-triiodothyronine promotes survival and axon elongation of embryonic rat septal neurons. Brain Res 647:148-152.

Fisher DA, Dussault JH, Sack J, Chopra IJ (1977) Ontogenesis of hypothalamic-pituitary-thyroid function and metabolism in man, sheep and rat. Recent Prog Horm Res 33:59-116.

Fort P, Marty L, Piechaczyk M, el Sabrouty S, Dani C, Jeanteur P, Blanchard JM (1985) Various rat adult tissues express only one major mRNA species from the glyceraldehyde-3-phosphate-dehydrogenase multigenic family. Nucleic Acids Res 13:1431-1442.

Frade JM, Barde Y-A (1998) Microglia-derived nerve growth factor causes cell death in the developing retina. Neuron 20:35-41.

Fujita H, Tanaka J, Toku K, Tateishi N, Suzuki Y, Matsuda S, Sakanaka M, Maeda N (1996) Effects of GM-CSF and ordinary supplements on the ramification of microglia in culture: a morphometrical study. Glia 18:269-281.

Gandrillon O, Ferrand N, Michaille JJ, Roze L, Zile MH, Samarut J (1994) c-erbA alpha/T3R and RARs control commitment of hematopoietic self-renewing progenitor cells to apotosis or differentiation and are antagonized by the v-erbA oncogene. Oncogene 9:749-758.

Giulian D, Baker TJ (1986) Characterization of ameboid microglia isolated from developing mammalian brain. J Neurosci 6:2163-2178.

Giulian D, Young DG, Woodward J, Brown DC, Lachman LB (1988) Interleukin-1 is an astroglial growth factor in the developing brain. J Neurosci 8:709-714.

Gonzales-Scarano F, Baltuch G (1999) Microglia as mediators of inflammatory and degenerative diseases. Annu Rev Neurosci 22:219-240.

Göthe S, Wang Z, Ng L, Kindblom JM, Barros AC, Ohlsson C, Vennström B, Forrest D (1999) Mice devoid of all known thyroid hormone receptors are viable but exhibit disorders of the pituitarythyroid axis, growth, and bone maturation. Genes Dev 13:1329-1341.

Heppner FL, Roth K, Nitsch R, Hailer NP (1998) Vitamin E induces ramification and downregulation of adhesion molecules in cultured microglial cells. Glia 22:180-188.

Hickey WF (1999) The pathology of multiple sclerosis: a historical perspective. J Neuroimmunol 98:37-44.

Hodin RA, Lazar MA, Wintman BI, Darling DS, Koening RJ, Larsen PR, Moore DD, Chin WW (1989) Identification of a thyroid hormone receptor that is pituitary-specific. Science 244:76-79.

Kahn MA, Kumar S, Liebl D, Chang R, Parada LF, De Vellis J (1999) Mice lacking NT-3, and its receptor TrkC, exhibit profound deficiencies in CNS glial cells. Glia 26:153-165.

Kawaio A, Tsuneda M (1985) Functional development and maturation of the rat thyroid gland in the foetal and newborn periods: an immunohistochemical study. Acta Endocrinol 108:518-524.

Koenig RJ, Warne RL, Brent GA, Harney JW, Larsen PR, Moore DD (1988) Isolation of a cDNA clone encoding a biologically active thyroid hormone receptor. Proc Natl Acad Sci USA 85:5031-5035.

Kreutzberg G (1996) Microglia: a sensor for pathological events in the CNS. Trends Neurosci 19:312-319.

Lazar MA, Hodin RA, Darling DS, Chin WW (1988) Identification of a rat c-erbA-alpha-related protein which binds deoxyribonucleic acid but does not bind thyroid hormone. Mol Endrocrinol 2:893-901.

Lazar MA, Hodin RA, Darling DS, Chin WW (1989) A novel member of the thyroid/steroid hormone receptor family is encoded by the opposite strand of the rat c-erbA $\alpha$ transcriptional unit. Mol Cell Biol 9:1128-1136

Lechan RM, Qi Y, Berrodin TJ, Davis KD, Schwartz HL, Strait KA, Oppenheimer JH, Lazar MA (1993) Immunocytochemical delineation of thyroid hormone receptor $\beta 2$-like immunoreactivity in the rat central nervous system. Endocrinology 132:2461-2469.

Legrand J (1983) Hormones thyrö̈diennes et maturation du système nerveux central. J Physiol (Paris) 78:603-652.

Lima FRS, Trentin AG, Rosenthal D, Chagas C, Moura Neto V (1997) Thryoid hormone induces protein secretion and morphological changes in astroglial cells with an increase in expression of glial fibrillary acidic protein. J Endocrinol 154:167-175.

Lima FRS, De Freitas MS, Gomes FA, Gonçalves N, Moura Neto V (1998) Thyroid hormone action on astroglial cells from distinct brain regions during development. Int J Dev Neurosci 16:19-27.

Ling EA, Wong WC (1993) The origin and nature of ramified and amoeboid microglia: a historical review and current concepts. Glia 7:9-18.

Lissitzky S (1990) Thyroid hormones. In: Hormones: from molecules to disease (Beaulieu EE, Kelly PA, eds), pp 342-373. Paris: Hermann.

Liu W, Brosnan CF, Dickson DW, Lee SC (1994) Macrophage colony- 
stimulating factor mediates astrocyte-induced microglial ramification in human fetal central nervous system culture. Am J Pathol 145:48-53.

Mangelsdorf DJ, Thummel C, Beato M, Herrlich P, Schütz G, Umesono K, Blumberg B, Kastner P, Mark M, Chambon P, Evans RM (1995) The nuclear receptor superfamily: the second decade. Cell 83:835-839.

Marín-Teva JL, Almendros A, Calvente R, Cuadros MA, Navascués J (1999) Proliferation of actively migrating ameboid microglia in the developing quail retina. Anat Embryol 200:289-300.

Mellström B, Naranjo JR, Santos A, Gonzales AM, Bernal J (1991) Independant expression of the alpha and beta c-erbA genes in developing rat brain. Mol Endocrinol 5:1339-1350.

Michaelson MD, Bieri PL, Mehler MF, Xu H, Arezzo JC, Pollard JW, Kessler JA (1996) CSF-1 deficiency in mice results in abnormal brain development. Development 122:2661-2672.

Milligan CE, Cunningham J, Levitt P (1991) Differential immunochemical markers reveal the normal distribution of brain macrophages and microglia in the developing rat brain. J Comp Neurol 314:125-135.

Mitsuhashi T, Tennyson GE, Nikodem VM (1988a) Alternative splicing generates messages encoding rat c-erbA proteins that do not bind thyroid hormone. Proc Natl Acad Sci USA 85:5804-5808.

Mitsuhashi T, Tennyson G, Nikodem V (1988b) Nucleotide sequence of novel cDNAs generated by alternative splicing of a rat thyroid hormone receptor gene transcript. Nucleic Acids Res 16:5697.

Muller Y, Rocchi E, Lazaro JB, Clos J (1995) Thyroid hormone promotes BCL-2 expression and prevents apoptosis of early differentiating cerebellar granule neurons. Int J Dev Neurosci 13:871-885.

Muñoz A, Bernal J (1997) Biological activities of thyroid hormone receptors. Eur J Endocrinol 137:433-445.

Neveu I, Arenas E (1996) Neurotrophins promote the survival and development of neurons in the cerebellum of hypothyroid rats in vivo. J Cell Biol 133:631-646.

Obregon MJ, Mallol J, Pastor R, Morreale de Escobar G, Escobar del Rey $\mathrm{F}$ (1984) L-thyroxine and 3,5,3'-trioiodo-L-thyronine in rat embryos before onset of fetal thyroid function. Endocrinology 114:305-307.

Oppenheimer JH, Schwartz HL (1997) Molecular basis of thyroid hormone-dependent brain development. Endocr Rev 18:462-475.

Perry VH, Lawson LJ, Reid DM (1994) Biology of the mononuclear phagocyte system of the central nervous system and HIV infection. J Leukoc Biol 56:399-406.

Porterfield SP, Hendrich CE (1992) Tissue iodothyronine levels in fetuses of control and hypothyroid rats at 13 and 16 days of gestation. Endocrinology 131:195-200.

Porterfield SP, Hendrich CE (1993) The role of thyroid hormones in prenatal and neonatal neurological development. Current perspectives. Endocr Rev 14:94-106.

Puymirat J (1992) Thyroid receptors in the rat brain. Prog Neurobiol 39:281-294.

Puymirat J, Miehe M, Marchand R, Sarliève L, Dussault JH (1991)
Immunocytochemical localization of thyroid hormone receptors in the adult rat brain. Thyroid 1:173-184.

Rami A, Rabié A (1988) Effect of thyroid deficiency on the development of glia in the hippocampal formation of the rat: an immunocytochemical study. Glia 1:337-345.

Rodríguez-Peña A (1999) Oligodendrocyte development and thyroid hormone. J Neurobiol 40:497-512.

Sorokin SJ, Hoyt RF, Blunt DG, McNelly NA (1992) Macrophage development: II. Early ontogeny of macrophage populations in brain, liver, and lungs of rat embryos as revealed by a lectin marker. Anat Rec 232:527-550.

Strait KA, Schwartz HL, Perrez-Castillo A, Oppenheimer JH (1990) Relationship of c-erbA mRNA content to tissue triiodothyronine nuclear binding capacity and function in developing and adult rats. J Biol Chem 265:10514-10521.

Strait KA, Schwartz HL, Seybold V, Ling NC, Oppenheimer JH (1991) Immunofluorescence localization of thyroid hormone receptor protein $\beta 1$ and variant $\alpha 2$ in selected tissues: cerebellar Purkinje cells as a model for $\beta 1$ receptor-mediated developmental effects of thyroid hormone in brain. Proc Natl Acad Sci USA 88:3887-3891.

Streit SJ, Kreutzberg GW (1987) Lectin binding by resting and reactive microglia. J Neurocytol 16:249-260.

Suzuki S, Kobayashi H, Sekine R, Kumagai M, Mikoshiba M, Mori J, Hara M, Ichikawa K, Hashizume K (1997) 3,5,3'- Triiodo-L-thyronine potentiates all-trans-retinoic acid-induced apoptosis during differentiation of the promyeloleukemic cell HL-60. Endocrinology 138:805-809.

Théry C, Chamak B, Mallat M (1991) Cytotoxic effect of brain macrophages on developing neurons. Eur J Neurosci 3:1155-1164.

Thompson CC, Weinberger C, Lebo R, Evans RM (1987) Identification of a novel thyroid hormone receptor expressed in the mammalian central nervous system. Science 237:1610-1614.

Trentin AG, Rosenthal D, Moura Neto V (1995) Thyroid hormone and conditioned medium effects on astroglial cells from hypothyroid and normal rat brain: factor secretion, cell differentiation and proliferation. J Neurosci Res 41:409-417.

Varga F, Luegmayr E, Fratz-Zelman N, Glantschnig H, Ellinger A, Prinz D, Rumpler M, Klaushofer K (1999) Tri-iodothyronine inhibits multilayer formation of the osteoblastic cell line, MC3Y3-E1, by promoting apoptosis. J Endocrinol 160:57-65.

Walter IB (1996) Triiodothyronine exerts a trophic action on rat sensory neuron survival and neurite outgrowth through different pathways. Eur J Neurosci 8:455-466.

Wegiel J, Wisniewski HM, Dziewiatkowski J, Tarnawski M, Kozielski R, Trenknert E, Wiktor-Jedrzejczak W (1998) Reduced number and altered morphology of microglial cells in colony stimulating factor-1deficient osteopetrotic op/op mice. Brain Res 804:135-139. 